\title{
TOWARDS THE STABILISATION OF ZIMBABWEAN ENGLISH: PROGRESS AND PROSPECTS
}

\author{
Clemenciana MUKENGE \\ Linguistics Department, University of Zimbabwe \\ cmukenge@gmail.com
}

Manuscript received 5 November 2019

Manuscript accepted 7 June 2021

*Corresponding author

https://doi.org/10.33736/ils.2789.2021

\begin{abstract}
The systematic description of African Englishes, including Zimbabwean English (ZE) is gradually increasing in the continent's ongoing sociolinguistic research. The purpose of this contribution is to investigate the progress currently made in stabilising the Zimbabwean variety of English since its emergence in the 1980s using Schneider's (2007) Dynamic framework for stabilisation of "New Englishes". ZE is perceived to be at the nativisation stage, encompassing indigenisation of Standard English before a full adoption into a new socio-cultural context. Evidence of nativisation includes phonological innovations and structural indigenisation of English. It is noted that complete nativisation would follow after full adoption and functionalisation by the speech community. Furthermore, the study establishes that the task at hand is to carry out in-depth research that probes deeper into ZE's evolution process; explaining its key structural features and its sociolinguistic traits. This will uncover its general linguistic behaviour, functional role and possibly strengthen its visibility, use and eventual growth. One major limitation of the study is that its focus is restricted to the Zimbabwean variety of English. Recommended future studies should include comparative studies of the development of "New Englishes" in other outer circle regions, so as to methodologically inform the stabilisation process of ZE.
\end{abstract}

Keywords: Zimbabwean English (ZE); New Englishes; stabilisation; progress; prospects 


\section{Introduction}

Zimbabwean English (ZE), spoken by the indigenous people who constitute the majority, emerged following linguistic contact between indigenous languages and Standard British English, introduced by the former colonial administration (Kadenge, 2009; Makoni, 1993). According to Marungudzi (2016), initially, the development of ZE was influenced by South African English, Afrikaans and other African languages, following a wave of immigrations from the Cape Colony and Orange Free State in the 1890s. These languages arguable introduced and reinforced many linguistic features which had an impact in developing a local variety of English. Nonetheless, after Zimbabwe's independence in the 1980s, there was a steady decline in the influence of Afrikaans and South African English, with a notable preference for British English which was progressively considered neutral and prestigious by the educated elite (Marungudzi, 2016). Subsequently, ZE is mainly derived from linguistic contact between Standard British English and indigenous languages as shall be explained later.

ZE is similar to other African Englishes spoken as a second language, but it is generally understudied (Cutler et al., 2006; Marungudzi, 2016). Existing studies explore ZE from phonological and morphological perspectives, examining the vowel systems of both Standard English and local languages (Shona, for example), in order to describe its linguistic structure (see Kadenge, 2009; Kadenge et al., 2009; Magura, 1985; Makoni, 1993; Mareva et al., 2016; Marungudzi, 2016; Ngara, 1982). Beyond these descriptions, no profound research on ZE has been carried out so far, impeding its growth. Thus, in most cases, it is dismissed as mere "codeswitches" (Mareva et al., 2016) or "errors" (Makoni, 1993) made by second language speakers. As Kortmann et al. (2004) suggest, before acceptance and functionality can occur, indepth systematic linguistic descriptions of New Englishes are important in building confidence and autonomy of these varieties. The significance of research into "New Englishes" is emphasised by Platt and Weber (1980), who observe that research enables the recognition of a variety's norms by the speech community [Kachru's (1992) speaker awareness], in the processes of its localisation.

Since linguistic research underlines the progress and development of new varieties of English (Schneider, 2007), taking lead from other African countries which have officialised New Englishes, such as Nigeria, Ghana and Sierra Leone, the purpose of this contribution is to explore the progress made so far in the stabilisation of ZE since its emergence in the 1980s. The process of stabilisation is a common subject in the area of development of non-native varieties of English and can be best described in relation to the development of English in former colonies of England (Schneider, 2007). According to Grainger and Mills (2016), language stability is approximately the opposite of language change, denoting resistance to linguistic change or loss. Schneider (2007) agrees that stability signifies the linguistic structures that are not subject to change. It is a process of "relocating and rerooting" of English in the post-colonial contexts, beginning with identity construction to dialect birth (Schneider, 2007, p. 1). Thus, in Schneider's (2007) view, 
complete stabilisation of a variety entails development of a documented corpus which describes the systematic ways in which the language is used or ought to be used. Given this view, the main aim of this study is to explore the stage at which ZE is, along the stabilisation continuum, guided by Schneider's (2007) dynamic model which recognises five stages of variety development.

\section{An overview of New Englishes}

New Englishes were recently popularised and are currently occupying a centre stage of applied and theoretical linguistic research worldwide. The term "New Englishes" refers to the regional and national varieties of English used in areas where it is nonnative to the majority of the population, and which are different from the historically established British and American standards (Dawson, 2011; Guerra, 2014). The non-native nature of New Englishes is also pursued by McArthur (1992), who states that it is "a term in linguistics for a recently emerging and increasingly autonomous variety of English, especially in a non-Western setting such as India, Nigeria, or Singapore" (pp. 688-689). A related definition states that "the term New Englishes has been used to refer to the localised forms of English found in the Caribbean, West and East Africa, and parts of Asia" (Bolton, 2003, p. 2). Makoni (1993) emphasises that "New Englishes" are distinct from native dialects such as American English or Scottish English, they are recent varieties emerging as a result of various socio-cultural factors. They acquire new features and, hence, are functional in their own right as they perform elucidation, neutralisation, self-identification and other roles (Kadenge, 2009).

Jenkins (2006, cited in Dawson, 2011, p. 1), distinguishes between two types of world Englishes: the "new Englishes" (note the small letter $n$ ) and the "New Englishes" (note the capital letter N). The first type, "new Englishes" (varieties of English used in areas where it is native to the majority of the population) originated from what he calls "first diaspora" countries, USA, Canada, Australia, New Zealand and partly South Africa. "New Englishes" (regional and national varieties of English used in areas where it is non-native to the majority of the population) emerged from a situation where English is learnt as a second language or is a language existing within a wide range of languages in the "second diaspora" (Jenkins, 2006). For example, Indian English, Nigerian English, Singaporean or Philippine English. In Jenkin's (2006) view, the "New Englishes" differ linguistically, culturally, functionally and ideologically from the "new Englishes". Schneider (2003) explains that "New Englishes" in Africa and other ex-colonial nations emerged in the post-colonial settings, shaped by "idiosyncratic historical conditions and contact settings" (p. 233).

Given the reality that "New Englishes" in Africa are a result of contact between Standard English and local languages, their linguistic properties may differ from one country to another. In this regard, Xu (2017) identifies subcategories of varieties of African Englishes as: Standard English, second language varieties of English (Southern Africa), English based-Pidgins (West Africa) and English-based Creoles (West Africa). Similarly, African Englishes are classified into: (1) South African English (spoken in South Africa, and widely spoken as a second language, mainly resembling English spoken in Zimbabwe, Namibia, Zambia, Kenya); (2) West African 
English (spoken by non-native speakers of English in Ghana, Nigeria, Liberia and Cameroon, and varies from place to place), and (3) East African English (spoken as a second language in Kenya, Tanzania and Uganda, and very similar to English spoken by locals in Zimbabwe, Malawi, Zambia and South Africa) (Bolton, 2003).

Currently, there is an emergence of African Englishes, and examples of legitimate non-native varieties of English include Nigerian English, Ghanaian English and Sierra Leon English. According to Nordquist (2019) and Igboanusi (2001), Nigerian English and its sub-varieties (Nigerian Pidgin) exist today owing to the nativisation of English in Nigeria. Nigerian English "is not limited to the usual features of transfer of phonological, lexical, syntactic and semantic patterns of Nigeria languages into English, it also includes the creative development of English, including the evolution of distinctively Nigerian usages, attitudes and pragmatic use of languages" (Igboanusi, 2001, p. 361). Following examples of Nigerian Pidgin and Sierra Leonean Krio, Ghana officialised Ghanaian English in 2012, which is distinct from British English mainly marked by unique pronunciation. The move to embrace a new standard of Ghanaian English was inspired by the need to empower people to speak in a natural style without having to mimic the British accent (Jian, 2012). At this point, it is worth noting that ZE, displaying distinct linguistic features, is a type of "New English". Thus, in order to understand its process of stabilisation as per this study's objective, there is need to explore the linguistic context within which ZE emerges and later a body of its theoretical and linguistic descriptions.

\section{A sociolinguistic situation of Zimbabwe: the place of English}

The purpose of this section is to highlight the main sociolinguistic attributes of the Zimbabwean speech community. This background is significant as it sheds light on the general linguistic behaviour of the speech community that informs language development, policy and planning. It also enlightens the functional role of English language in Zimbabwe. Zimbabwe is a polyglossic nation where various languages are spoken. In terms of language distribution, approximately $71 \%$ of this population is Shona-speaking, $16 \%$ speaks Ndebele, $11 \%$ speaks "minority" indigenous languages (Nambya, Tonga, Kalanga, Sotho, Venda, Shangane), $1 \%$ speaks Asian languages and another 1\% speaks English (Magwa, 2010). Given the diversity of languages spoken within the Zimbabwean inland, it is clear that the country is inhabited by multiple ethnicities and nationalities.

Amongst an estimate of 23 languages spoken in the country, only 16 are officially recognised in accordance with the Constitution of Zimbabwe, Amendment 20 (2013), namely, Chewa, Chibarwe, English, Kalanga, Khoisan, Nambya, Ndau, Ndebele, Shangani, Shona, Sign Language, Sotho, Tonga, Tswana, Venda and Xhosa. Nevertheless, this was a declaration without implementation, given that in practice, English alone continues to dominate all official discourses, and to a less extent Shona and Ndebele which are recognised as national languages (Kadenge, 2009; Mashiri, 2009; Ngara, 1982; Nhongo, 2013). Essentially, English in Zimbabwe is the main medium of communication in all formal domains such as media, education, legislation, business, politics and science and technology. Also, unlike indigenous languages, English has a nationwide geographical coverage, conveying a higher 
status than the rest (Kadenge \& Nkomo, 2011). The prominent status of English is in fact a global phenomenon, and Troike (1977) traces its origin in the $17^{\text {th }}$ century as he notes that:

From a minor language in 1600, English has in less than four centuries come to be the leading language of international communication in the world today. This remarkable development is ultimately the result of the $17^{\text {th }}, 18^{\text {th }}$ and $19^{\text {th }}$ century British success in conquest, colonisation and trade. (p. 2)

Troike's (1977) assertion is consolidated by Makoni's (1993) view that English and its elevated status, in Zimbabwe and other Anglophone African countries, is a linguistic legacy of the former British colonial administration. In these countries, English has been retained and elevated into an official national language status. Thus, in Zimbabwe, in as much as other African countries, English is spoken as a second language by the majority of black populations, and as a first language by the minority groups such as Europeans, Indians and mixed races, resulting in an inevitable bilingual society. Further, according to Makoni (1993), its importance is reflected by the increasing number of African elites who continue to acquire English as a first language at the expense of their mother tongues. Thus, having provided a synopsis of the sociolinguistic profile of Zimbabwe from which a new variety of local English is emerging, the following section shifts focus to the various linguistic descriptions of ZE, constituting some of the key linguistic researches carried out in Zimbabwe so far following its emergence in the 1980s.

\section{Scholarly descriptions of Zimbabwean English}

ZE has been described from various linguistic perspectives, including phonological, morphological, syntactic, lexical, grammatical and pragmatic. According to Makoni (1993), the interest in characterising ZE is emphasised in order to arouse awareness of its properties, which define it as a new variety of English. These descriptions are also key in altering the status of this form of new English, although they are inadequate in the task of elevating it into an autonomous language (Marungudzi, 2016). Interests in ZE bourgeoned from the imminent depictions of varieties of English spoken around the world, known as "New Englishes". Bolton (2003) confirms that, research in New Englishes was popularised in the 1980s, even in the English native countries such as Britain and America, following accounts of international Englishes in print media. In this context, Kachru (1992) claims that the advent of "New Englishes" marked a significant "paradigm shift" in the study of English worldwide (p. 4).

Marungudzi (2016) categorises studies on ZE into two: sociolinguistics and theoretical linguistic studies. In the sociolinguistic strand, he identifies Ngara (1982), who explains that English was imposed in Zimbabwe by the former colonial government. Its initial contact and interaction with Shona and other indigenous languages produced a unique identifiable variety of English spoken in Zimbabwe, which has clear phonological properties of Shona. Schneider (2003) confirms that 
"New Englishes" in Africa and other ex-colonial nations emerged in the post-colonial settings, shaped by "idiosyncratic historical conditions and contact settings" (p. 233). He adds that no comprehensive theory has been developed to explain the concept of "New Englishes". In another sociolinguistic study that investigated the type of English spoken in Zimbabwe, influenced by Platt and Weber's (1980) lectal range, Magura (1985) discovered that there are forms of Englishes spoken in Zimbabwe by identified groups: acrolect, mesolect and basilect. Magura's (1985) study attests to the multi-variation structure of English language, as spoken by specific social groups for specialised purposes. However, Magura (1985) and Ngara (1982) only indicate the variant nature of English language that is spoken in Zimbabwe, and do not precisely explore the sociolinguistic behaviour of ZE. Nevertheless, Makoni (1993) for the first time addressed the key question of whether or not a Zimbabwean variety of English exists.

Furthering the studies of Ngara (1982) and Magura (1985), Makoni (1993) implements psycholinguistic and sociolinguistic approaches to explain the structural development of ZE. In this context, he employs universal linguistic properties of the first language (L1) of the users (Shona), to describe the new variety of English. In his conclusion, Makoni (1993) claims that, ZE is an interface between L1 (Shona) and L2 (English) and is established based on the environment within which the L2 is acquired under the influence of L1. According to Makoni (1993), L1 interference manifests in two ways: language transfer and cross-linguistic influence. It is a feature of the Error Analysis theory, developed by Ellis (1992) which claims that L1 is responsible for errors made by learners of English as a second language, and refers to the variety of English produced by these learners as a learner variety. Mutonya (2008) consents as he argues that African Englishes are linguistically attained through learning processes of acquiring English by non-native speakers. In this regard, Makoni (1993) claims that ZE, as well as other African varieties of English, are mere interlanguage errors. He also maintains that the "appropriacy" of ZE should be measured against native speaker standard varieties.

However, Makoni's (1993) claims are non-applicable to similar contexts such as Nigeria and Ghana, whose Englishes stand on their own right and have gained autonomy and legitimacy. Although Makoni may be correct to argue that ZE is a result of interlanguage resulting from $\mathrm{L} 1$ interference in the acquisition of English, there is a need to remember that language acquisition is a much more complex process than that. Such claims limit the language acquisition scope into psychological and cognitive abilities, yet according to Marungudzi (2016), it is a broad enterprise, involving various other socio-cultural aspects in the speech environment. Contrary to Makoni (1993), Mlambo (2009) takes up the debate of the existence of a new variety of ZE, affirming its presence. According to Mlambo (2009), $Z E$ is a self-sufficient language, disengaged from interlanguage processes. Echoing Platt and Weber (1980) and Magura (1985), Mlambo (2009) identifies sub-varieties of English in Zimbabwe, arguing that, apart from native English, there are three other forms (acrolect, mesolect and basilect), as well as what he calls the nearnative variety.

Amongst theoretical linguistic studies of ZE, Kadenge et al. (2009) describe this variety from a phonological point of view. Kadenge et al. (2009) make a 
comparative assessment of the vowel systems of Shona and English spoken by learners of English as a second language in order to establish the characteristics of Zimbabwean English. According to Kadenge et al. (2009), the vowel system of English produced by the learners indicates a strong first language cross-linguistic influence. They agree with Makoni (1993) that L1 (Shona) has an influence on the production of L2 (English) producing a variety of English as a result of interlanguage contact. Linguistic interference occurs as a result of various phonological processes such as vowel substitution, vowel length reduction, monophthongisation of diphthongs and glide epenthesis (Kadenge et al., 2009). Their argument rests on the claim that the new variety of ZE developed partly due to the acquisition of English as a second language by L1 Shona speakers. They support this claim by indicating that complex English diphthongs, triphthongs and phonemically long vowels, which are non-existent in L1 (Shona), are simplified in the English speech by Shona speakers, through substitution with glide epenthesis or monophthongs, characteristic of the Shona vowel system.

In addition, Kadenge (2009) concurs with Makoni's (1993) concept of ZE being produced as a result of interlanguage contact. However, Kadenge (2009) sees this variety beyond just being a set of "errors" made by $L 2$ learners. He notes that "based on the sociolinguistic status and localised phonological features of the English that is spoken in Zimbabwe, this study concludes that this distinct variety of English is legitimately 'owned' by Zimbabweans" (Kadenge, 2009, p. 147). Kachru (1992) vehemently rejects the descriptions of "New Englishes" in terms of interlanguages. These are perceived as distinct, systematic, non-native varieties of English, independent of native British and American Englishes. For Kachru (1992), African Englishes, and hence ZE, are an outcome of the processes of "indigenisation" or "nativisation", involving language change to meet the communicative needs of non-native users of English language. According to Kachru (1992), through indigenisation, English is assimilated, accommodated and adopted by native speakers to suit their circumstances.

From the review outlined above, it is apparent that the descriptions of ZE amount to a framework, delineating linguistic attributes of the variety. It is also true that these descriptions are not detailed in their characterisations of the linguistic structure of the variety. As Marungudzi (2016) rightly argues, mere depictions of ZE only contribute towards the debate of the ontological status of the new variety. Thus, since Zimbabwean linguists have not yet committed to execute an in-depth research on ZE, this has implications for its development and stabilisation. This problem is not unique to the Zimbabwean context. Precisely, research in the area of "New Englishes" in Southern Africa (for example, Malawi, Zambia and Zimbabwe) is generally limited, contrary to West and East Africa, (for example, Nigeria and Ghana) as evidenced by the milestones covered in terms of elevation of local varieties of English (Marungudzi, 2016; Schmied, 1996). The following section endeavors to establish the status of ZE, guided by Schneider's (2007) systematic model for variety stabilisation. 


\section{Towards the stabilisation of Zimbabwean English}

In an attempt to determine how best ZE can be stabilised, this section discusses some scholarly criteria for determining standard varieties and for systematic stabilisation of World Englishes. Kachru's (1992) Three Circles model would be used to determine the nature of ZE as a form of "New Englishes", and Schneider's (2007) Dynamic Model is employed to explain the process of variety stabilisation, focusing on stages and socio-cultural conditions prerequisite for the development of ZE into an autonomous language.

In his Three Circles Model, Kachru (1992) presents three circles to represent the plurality of English in the world: The "inner circle" incorporating United Kingdom, United States of America, Australia, Canada and New Zealand; the "outer circle" including Zimbabwe, Nigeria, Singapore and parts of South Africa; and the "expanding circle" encompassing most European, Middle Eastern, South American, Francophone African and Asian countries. According to Kachru (1992), in the inner circle, the users of English are endo-normative, speaking English as a native language (ENL). In the outer circle users are norm-developing, speaking English as a second language (ESL) and in the expanding circle, speakers are exo-normative, using English as a foreign language (EFL). In Kachruan scheme, Zimbabwe belongs to the ESL region, hence the nature of the Zimbabwean variety of English is normdeveloping. This entails a process of developing a new form of English, and in this case "nativisation" through a linguistic contact of standard British and indigenous languages. Kachru's (1992) nativisation concept is important as it explains how new varieties of English are established, bridging the gap between the norm-producing inner circle and the norm-developing outer circle.

Within Schneider's (2007) dynamic framework of the evolution of "New Englishes", it is expected that the speech community would undergo five consecutive phases in order to stabilise ZE. The first stage according to this model, known as "the foundation" phase, is characterised by cross dialectal contact and limited exposure to local languages. In the outer circle, it incorporates a stage when English is adopted for use on a regular basis by non-English speakers, following an extended settlement by English speaking settlers. In Zimbabwe, this phase was experienced following the advent of European settlers, resulting in language contact between English and indigenous languages. At the second phase, termed "exonormative stabilisation", English is widely spoken, with the native settler speakers providing for the stable usage. The settler norm, in the form of written and spoken British English is accepted as a standard linguistic model. Typically, there is borrowing, coinages and adoptions from indigenous languages, where some of the words remain local and some are diffused into the international English vocabulary (Schneider, 2007). Corresponding to this phase, in Zimbabwe, during the colonial period, in the mid-nineteenth century, the dominance of English was characterised by its use as the sole language of instruction in the entire education system. Chimhundu (1993) explains that English enjoyed a privileged status, "while African languages continue to be downgraded in the schools and vernacularized outside in the wider community" (p. 57). 
The current stage of development of ZE conforms with Schneider's third phase, the most central stage in the variety evolution process underlying this model, known as "nativisation". This is where both standard English and the indigenous languages become intertwined, forming a new local variety of English with new forms and lexical structures, characterised by new words, derivations and loan words. Kachru (1992, p. 235) emphasises that "nativisation is the linguistic readjustment a language undergoes when it is used by members of another speech community in distinctive socio-cultural contexts and language contact situations". In this regard, full nativisation entails that English becomes indigenised and fully adopted in new socio-cultural contexts of the outer circle, an indication of functional nativeness of the language (Schneider, 2007). However, ZE is arguable at the budding stage of nativisation seeing that, despite clear linguistic signs of localised English, it is not yet established or fully adopted. The nativisation of English in Zimbabwe became apparent in the post-independence era (1980s), during which the former coloniser's standard variety and indigenous languages (particularly Shona and Ndebele) began to entangle, developing a local English-based identity. According to Schneider (2007), the hybrid varieties of English significantly mirror the new identity of the speakers, based on lexicalisation styles, syntax, discourse and genres. In agreement, ZE, a uniquely Zimbabwean variety, is slowly gaining acceptance in informal and social settings, creating a sense of identity amongst its users, locally and abroad. It is characterised by heavy lexical borrowing, phraseological and grammatical innovations, as well as a unique accent.

Whilst ZE is experiencing structural nativisation, developing distinctive features of its own, there is evidence for this development in the speech of ESL speakers. At the lexical level, distinct terms, mostly high-frequency words, adopt marked usages, diverse from the standard norm. Some examples of the most common unconventional uses of English by locals and their purported meanings include the following:

$\begin{array}{ll}\text { Small house } & \text { "mistress" } \\ \text { Slay queen } & \text { "a young woman who maintains a trendy lifestyle" } \\ \text { Yellow bone } & \text { "a light skinned person" } \\ \text { Mother } & \text { "any elderly woman" } \\ \text { Father } & \text { "any elderly man" } \\ \text { Boss } & \text { "anyone considered a respectable gentleman" } \\ \text { Bullet } & \text { "beautiful woman" } \\ \text { Aunt } & \text { "house maid or helper" }\end{array}$

Grammatical nativisation manifested in ZE typically comprises phenomena such as new word formation products (for example, mask up "wear masks", condomise "use condoms" and wise-up "be wise"); localised phrases (for example, hashtag "curtesy of") and non-standard assignment of English verb tenses (for example, the tendency to use "send" as a past tense particle), signalling indigenous language influence (Toews, 2009). Toews (2009) explains the differences in the realisation of verb tenses between Standard British English and Shona language as emanating from the fact that Shona tenses are grounded on a precedence/subsequence framework as opposed to the English based past, present 
and future tense. Makoni (1993) adds that "syntactically, there is a tendency to use the present progressive in Zimbabwe where Standard English speakers use the simple present" (p. 103). An example that supports Makoni's sentiment is that of the inclination to say "I am wanting to say something", whose standard grammatical equivalent would be "I want to say something".

ZE is also characterised by restructuring of the English language vocabulary, most conspicuously in the use of loan words from indigenous languages. For example, some common terms borrowed from Ndebele and Shona include: indaba "conference", lobola "bride's price" and mbira "musical instrument". In addition, locals show a marked local accent when speaking English, which can be described as a transfer from the phonology of indigenous languages. In light of this, Kadenge et al. (2009) refer to the challenges faced by Shona speakers in pronouncing English diphthongs, triphthongs and long vowels, which are non-existent in local languages. These are arguably substituted with glide epenthesis and monophthongs, producing a foreign English accent. In essence, Kadenge et al. (2009) posit that the prevailing ZE accent is significantly affecting the status of English in the country and is increasingly evolving into a source of identification. Makoni (1993) accentuates the notion of English nativisation at a phonological level when he acknowledges the distinction in pronunciation between L1 and L2 speakers of English in Zimbabwe.

As the emerging norms of the hybrid variety of English are now evident and apparent in the speech of ESL speakers, they are currently restricted and not yet reflected in all linguistic and socio-political reality, and not yet codified. In view of this, Kadenge (2009) warns that although there are some known linguistic features that are peculiar to $Z E$, it is not yet possible to identify all the strict linguistic traits that are common to all speakers of the variety. Consequently, ZE has not yet been sufficiently recognised, with its existence so far acknowledged by a handful of scholarly descriptions as conferred above. This reality attests to an ongoing process of nativisation. Thus, as the range and depth of use of the new variety has not yet gained momentum, there is still a long way to linguistic autonomy, followed by acceptance and adoption. According to Schneider (2007), "New Englishes" are subject to full nativisation only after they have been recognised and copiously adopted in the outer circle. Thus, to expedite the development of ZE and full nativisation, the variety needs to be used regularly and precisely, in order to enhance speaker awareness as suggested by Schneider $(2003,2007)$. Of great interest is the role of researchers in the fields of linguistics, language planning and teaching, as well as historians and other concerned stakeholders. Researchers are tasked with enhancing the recognition of the naturally occurring ZE, through broadening research into this variety. Research enquiry needs to go beyond mere descriptions of the variety, and probe deeper into its evolution process, explaining its key linguistic structural features and its sociolinguistic traits such as the patterns of use and challenges. This will be vital in exposing the general linguistic behaviour and functional role of ZE, and possibly strengthen its visibility, use and eventual growth. It will also enable the Zimbabwean linguistic community to keep up with the sociolinguistic reality of the emerging variety of English. Moreover, linguistic research needs to enquire into the viable methods of accelerating the process of English nativisation and their implementation strategies. 
In Schneider's (2007) fourth phase, the "endonormative stabilisation" stage, the process of nativisation is completed. In this stage, a new variety of English with accepted local norms and standards emerges, whilst the Standard English may be retained as an official language of administration. This phase is only possible in politically independent former colonies, and is triggered in the post-colonial period by what he refers to as "some exceptional, quasi-catastrophic political event" (Schneider, 2003, p. 250). He asserts that at this stage, dictionary codification of the accepted local norms and their use in grammar books and creative fiction occurs. Examples of countries that have attained "endonormative stabilisation" include Singapore and India. According to Schneider (2007):

... by now Singapore has clearly reached phase 4 of the cycle. The country's unique, territory-based, and multicultural identity construction has paved the way for a general acceptance of the local way of speaking English as a symbolic expression of the pride of the Singaporeans in their nation. (p. 160)

Similarly, India has accomplished the "endonormative stabilisation" phase, establishing Indian English, although research into regional and social dialects of this variety is still ongoing (Mukherjee, 2007, p. 179). Schneider's (2007) "endonormative stabilisation" would be the next stage for ZE, after nativisation has been successfully attained. It will entail standardising through dictionary making and developing grammar handbooks. Nonetheless, concern over which linguistic norms to accept and adopt prevails, given that absolute linguistic correctness is unlikely as norms change from one context to another. As Schneider (2003) posits, it would be more ideal to allow the Zimbabwean speech community to define its own standards of English through linguistic practice. Codification would be followed by "differentiation", which constitutes Schneider's (2007) final phase of variety development. It involves establishing sub-group identities based on diversification of the language, forming dialectical differences within the variety. Differentiation is elaborated in Schneider's (2007) assertion that, "once a solid national basis has stabilised, one's global, external position is safe and stable, as it were, and this allows for more internal diversification" (p. 253).

According to Schneider (2003), the phases in the Dynamic Model may overlap, or their completion may not be fully attainable, hence the adoption of a new variety may vary from one area or group to another, and various activities may occur synchronously. Mukherjee (2007) adds that, for a variety to transcend from nativisation to endonormative stabilisation, there must be some sort of arbitrary agreement in a speech community, concerning the status and significance of the language. Since Zimbabwe is ready and politically inclined for "endonormative stability" which requires political independence, the language users have the power to decide on their own on the status of ZE without external interference. The attainment of political independence from colonial rule in 1980 culminated in the new government's commitment to develop and maintain indigenous languages in the post-colonial phase (Makoni, 1993). Although the post-independence language policies lack tangible implementation strategies, there is a clear effort to elevate the status of local languages, with the latest Constitution of Zimbabwe, Amendment 20 
(2013) declaring official recognition of 16 out of 23 local languages. Hence, within the independent state, the Zimbabwean speech community is able to assign language or variety status through the constitution provisions, breeding ground for "endonormative stability". Greenbaum (1996, as cited in Schneider, 2003) is thus correct to argue that, "political independence is a precursor of linguistic independence" (p. 247).

Summing up the discussion of ZE's status, it is worth noting that this variety is currently grappling with the nativisation phase, whilst preparing to enter the "endonormative stabilisation" stage. Evidence of nativisation includes phonological innovations and structural indigenisation of English. Full nativisation would only be accomplished after the variety of ZE has been fully adopted and functionalised by the speech community. As indicated earlier, within Schneider's (2007) model, nativisation would be shadowed by endonormative stabilisation and then differentiation. Thus, the task at hand in terms of ZE stabilisation is fostering its norms to enhance recognition and autonomy and later codification of the most salient features of the variety, through dictionary making and grammar handbooks. Lastly, research into the varieties of ZE and their sub-varieties will be carried out in the future, to mark the accomplishment of stabilisation.

Intrinsically, linguistic experts such as English language teachers, researchers, curriculum designers, applied linguists, language planners and language policy makers are faced with a difficult task of developing, testing, and implementing the new variety of ZE. Referring to this dilemma as a global phenomenon, Rajagopalan (2004) observes that:

Although today even more people accept the idea that there is such a thing as World English, very few of them seem to have realized that the full implications of admitting it are much more far reaching than they had hitherto imagined. (p. 1)

\section{Conclusion}

This study, which explored the progress of stabilisation of ze highlights that research on this variety is still minimal, amounting to narrow descriptions of its linguistic properties. It notes that, in terms of Schneider's (2007) model, ZE is currently at the nativisation stage, which encompasses indigenisation of native English before a full adoption into the new socio-cultural context. Implications for ongoing nativisation include the need for variety recognition and acceptance by the speech community. In light of this, the study established that in-depth linguistic research into ZE's structural features and sociolinguistic behaviour will be vital in enhancing its visibility, usage, functional role and gradual growth. This study is essential as it informs ZE stabilisation implementation policies through delineating the progress made so far in its development. Nonetheless, the study is not without limitations. One major limitation is that its focus is restricted to the development of the Zimbabwean variety of English. A consideration of similar outer circle contexts would have been pivotal in projecting a standard route for variety development. Recommended are comparative studies which focus on the growth of "New 
Englishes" in socio-historical contexts that resemble Zimbabwe which will methodologically inform the stabilisation process of ZE.

\section{References}

Bolton, K. (2003). Chinese Englishes: A sociolinguistic history. Cambridge University Press.

Chimhundu, H. (1993). The status of African languages in Zimbabwe. Southern Africa Political and Economic Monthly (SAPEM), 7(1), 57-59.

Constitution of Zimbabwe (2013). Amendment number 20: Act of 2013. Government Printers.

Cutler, A., Weber, A., \& Otake, T. (2006). Asymmetric mapping from phonetic to lexical representations in second-language listening. Journal of Phonetics, $34,269-284$.

Dawson, E. (2011). Beyond the postcolonial: A project in world Englishes. Transnational Literature, 3(2), 1-11.

Ellis, R. (1992). Understanding second language acquisition. Oxford: Oxford University Press.

Guerra, L. (2014) Using translation to teach native and non-native varieties of international English. e-TEALS: An e-journal of Teacher Education and Applied Language Studies, 5, 24-48.

Igboanusi, H. (2001). Varieties of Nigerian English: Igbo English in Nigerian literature. Journal of Cross-Cultural and Interlanguage Communication, 20(4), 361-378.

Jian, N. (2012, April 10). Ghana calls an end to tyrannical reign of the Queen's English. The Guardian International Edition. https://www.theguardian.com/world/2012/apr/10/ghana-calls-end-queensenglish\#: :text=Question\%3A\%20\%22Have\%20you\%20eat,Queen's\%20Engli sh\%20a\%20good\%20beating\%22

Kachru, B. B. (1992). World Englishes: Approaches, issues and resources. Language Teaching, 25(1), 1-14.

Kadenge, M. (2009). African Englishes: The indigenisation of English vowels by Zimbabwean native Shona speakers. The Journal of Pan African Studies, 3(1), 156-173.

Kadenge, M., Mabugu, P., \& Dube, S. (2009). Teaching English pronunciation via Shona: A classroom experiment (Zimbabwe). In L. Makalela (Ed.), Language teacher researcher in Africa (pp. 21-36). TESOL Publishers.

Kadenge, M., \& Nkomo D. (2011). The politics of the English language in Zimbabwe. Language Matters: Studies in the languages of Africa, 42(2), 248-263.

Kortmann, B., Burridge, K., Mesthrie, R., Schneider, E., \& Upton, C. (2004). A handbook of varieties of English: Morphology and syntax. Mouton de Gruyter.

Magura, B. J. (1985). Southern African Black English. World Englishes, 4(1), 251-256.

Magwa, W. (2010). Revisiting the language question in Zimbabwe: A multilingual approach to the language-in-education policy. Journal of Multicultural Discourses, 5(2), 157-168. 
Makoni, S. B. (1993). Is Zimbabwean English a type of new English? African Study Monographs, 14(2), 97-107.

Mareva, R., Kaburise, P., \& Klu, E. (2016). Teaching "Standard English" or local, codeswitched New Englishes in schools in "Outer Circle" countries? Insights from selected secondary school teachers of English in Zimbabwe. IRA International Journal of Education and Multidisciplinary Studies, 4(1), 113124.

Marungudzi, T. (2016). Towards a corpus-based study of Zimbabwean English: A state-of-the-art review and implications for further research. International Journal of English and Education, 5(2), 1-13.

Mashiri, P. (2009). Shonglish derisive names within the domestic environment among the Shona people of Zimbabwe. NAWA Journal of Language and Communication, 3(1), 66-80.

McArthur, T. (1992). The Oxford companion to the English Language. Oxford University Press.

Mlambo, M. (2009). A survey of the language situation in Zimbabwe: Is there a Zimbabwean variety of English? If so, who speaks it? English Today, 25(2), 18-24.

Mukherjee, J. (2007). Steady states in the evolution of new Englishes: Present-day Indian English as an equilibrium. Journal of English Linguistics, 35(2), 157187.

Mutonya, M. (2008). African Englishes: Acoustic analysis of vowels. World Englishes, 27(3/4), 434-449.

Ngara, E. A. (1982). Bilingualism, language contact and language planning. Mambo Press.

Nhongo, R. (2013). A national language policy for Zimbabwe in the twenty-first century: Myth or reality? Journal of Language Teaching and Research, 4(6), $1208-1215$.

Nordquist, R. (2019, October 14). Nigerian English-cultural and language differences. ThoughtCo Blog. https://www.thoughtco.com/what-is-nigerian-english1691347

Platt, J., \& Weber, H. (1980). English in Singapore and Malaysia. Oxford University Press.

Rajagopalan, K. (2004). The concept of World English and its implications for ELT. ELT Journal, 58(2), 111-117.

Schmied, J. (1996). English in Zimbabwe, Zambia and Malawi. In V. de Klerk (Ed.), Focus on South Africa (pp. 301-321). John Benjamins.

Schneider, E. W. (2003). The dynamics of new Englishes: From identity construction to dialect birth. Language, 79(2), 233-281.

Schneider, E. W. (2007). Postcolonial English: Varieties around the world. Cambridge University Press. 
Toews, C. (2009). The expression of tense and aspect in Shona. In O. Akinloye \& M. Lioba (Eds.), Selected proceedings of the $39^{\text {th }}$ annual conference on African linguistics (pp. 32-41). Cascadilla Proceedings Project.

Troike, R. (1977). The future of English. Editorial in The Linguistic Reporter.

$\mathrm{Xu}, \mathrm{X}$. (2017). Corpus-based study on African English varieties. Journal of Language Teaching and Research, 8(3), 615-623. 